\title{
Susceptibility of Phytoseiulus persimilis and Neoseiulus californicus (Acari: Phytoseiidae) to Commonly Used Insecticides Approved for Managing Arthropod Pests in Florida Strawberries ${ }^{1}$
}

\author{
Braden Evans, Karol Krey, and Justin Renkema ${ }^{2}$
}

\section{Florida Strawberry Production}

The Florida strawberry industry is valued at over $\$ 300$ million, accounting for 15,000 jobs and $15 \%$ of total US strawberry production (1). Owing to the subtropical climate, Florida strawberries are produced during the winter months, representing $100 \%$ of US winter strawberry production. Nearly all of Florida's strawberries ( 95\%) are grown in Hillsborough and Manatee counties, centered in the Plant City area. With high production costs and increasing price pressure from strawberry imports grown in Mexico, Florida producers are dependent on effective and efficient pest management programs (1) (Figure 1). The aim of this document is to inform Florida strawberry producers and Extension personnel on the compatibility of registered miticides and insecticides with commercially available predatory mites used as biological controls.

\section{Twospotted Spider Mite}

The most important arthropod pest in Florida strawberries is the twospotted spider mite, Tetranychus urticae Koch (1). The twospotted spider mite (TSSM) is a highly polyphagous pest of many horticultural crops throughout the world, with over 1,100 host plant species reported (2). In strawberry cultivation, TSSM inhabits the underside of developed leaves, forming silk webs and causing silvery-white patches (3). The TSSM uses its specially adapted mouthparts to pierce and suck the contents of individual plant cells (3). The feeding removes the sap from the cells, causing pale areas to appear on the upper surface of leaves (3). As TSSM continues to feed, the foliage begins to bronze, becomes dry, and the leaves drop off the plants (Figure 2). Total defoliation can result if an infestation is not controlled (3).

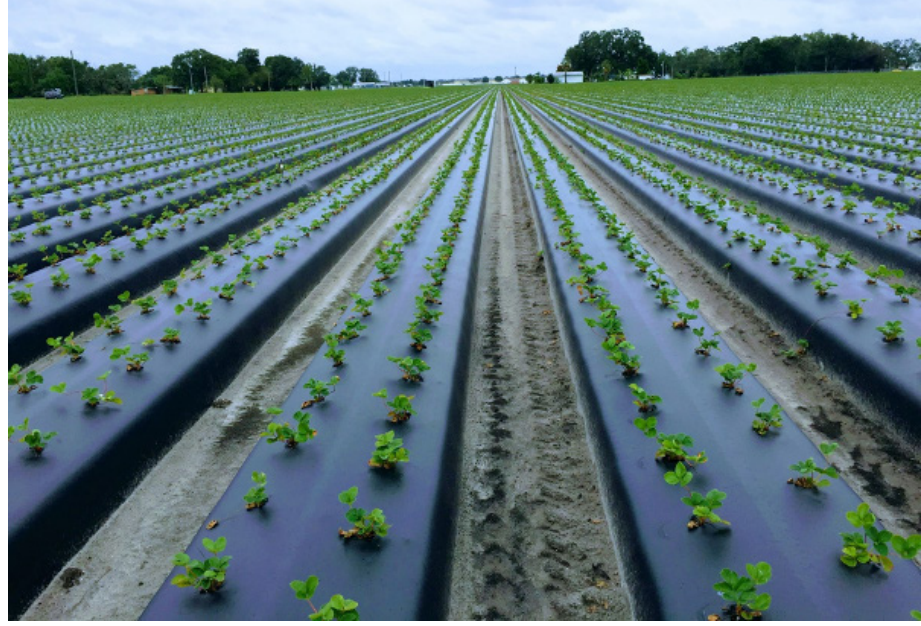

Figure 1. Early season Florida strawberry transplants. Florida strawberries are grown in raised beds with plastic mulch covering over sterilized soil at a production cost of over $\$ 27,000$ per acre (1). Credits: Babu Panthi, University of Florida.

1. This document is ENY-996, one of a series of the Entomology and Nematology Department, UF/IFAS Extension. Original publication date August 2018. Visit the EDIS website at http://edis.ifas.ufl.edu.

2. Braden Evans, postdoctoral associate; Karol Krey, postdoctoral associate; and Justin Renkema, associate professor; Gulf Coast Research and Education Center, UF/IFAS Extension, Wimauma, FL 33598. 


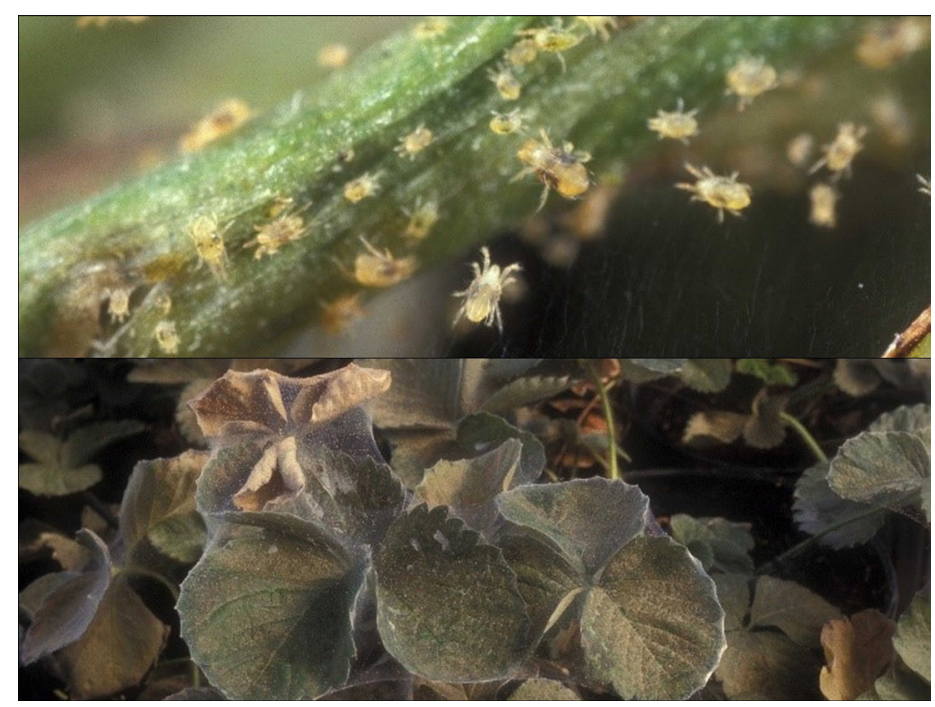

Figure 2. Adult and nymph twospotted spider mites (Tetranychus urticae) crawling along webs and stems, and the webbing and foliar discoloration on strawberry plants resulting from a severe twospotted spider mite infestation.

Credits: Lyle Buss and James Castner, University of Florida.

Many miticide products with different modes of action have been developed for TSSM control. Although strawberry producers are dependent on regular miticide applications, TSSM have demonstrated a propensity to develop resistance against a variety of compounds. In a review of reported cases of insecticide/miticide resistance, TSSM ranked first among all insect and mite pests, with control failures due to resistance reported from 95 different active ingredients (4). A high reproductive rate, a short life cycle, and the ability to reproduce without mating are counted among the biological attributes contributing to rapid and frequent resistance development in TSSM (5). Due to the tendency of TSSM to develop resistance to a wide array of miticides, biological control with predatory mites has been developed and is used for TSSM management in Florida strawberry.

\section{Phytoseiulus persimilis}

Phytoseiulus persimilis (Athias-Henriot) (Acari: Phytoseiidae) is a predatory mite that is used as a biological control agent against TSSM in a range of horticultural crops. $P$. persimilis is considered a specialist predator and feeds almost exclusively on mites in the genus Tetranychus (6, 7, 8). A native of Chile, $P$. persimilis has been introduced throughout the world as a biological control agent targeting spider mites in ornamental, vegetable, and fruit crops, including strawberries $(9,10,11)$.

Phytoseiulus persimilis features several characteristics that enable it to effectively control TSSM populations. It is a voracious and efficient predator, able to consume up to 20 individual TSSM of all life stages (eggs, larvae, nymphs, and adults) in a 24-hour period (12) (Figure 3). Nymph and adult $P$. persimilis actively seek out and feed on spider mites, but the larval stage is non-feeding. Under optimal environmental conditions, i.e., temperatures between $20-30^{\circ} \mathrm{C}$ $\left(68^{\circ} \mathrm{F}-86^{\circ} \mathrm{F}\right)$ and relative humidity above $60 \%$, P. persimilis may complete its entire life cycle within 5 days, as compared to spider mite development times of up to 20 days (12). Adult $P$. persimilis may live as long as 35 days, with highly fecund females producing 2-3 eggs per day, up to as many as 60 eggs in a lifetime (12). These various attributes have led to the commercialization and widespread use of $P$. persimilis as a biological pest management product.

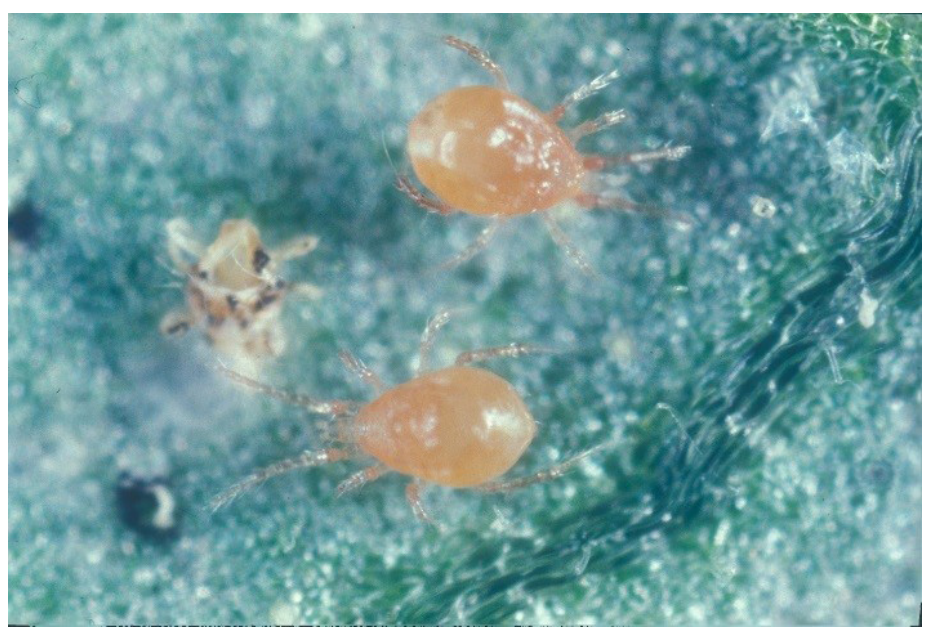

Figure 3. Adult Phytoseiulus persimilis with a recently consumed twospotted spider mite (Tetranychus urticae).

Credits: James Castner, University of Florida

Effective control of TSSM is dependent on appropriately timed introductions of predators into infested crops. Successful pest suppression has been reported when $P$. persimilis is applied early in a TSSM infestation, before pest populations increase to severely damaging levels (13, 14). In Florida strawberry fields, TSSM infestations are often patchily-distributed. Inoculation densities of five adult $P$. persimilis per plant can achieve an acceptable level of control. Although $P$. persimilis is blind, it can disperse rapidly throughout the crop, following chemical cues such as kairomones - the volatile compounds emitted by plants in response to feeding damage-as well as physical cues, including the webbing produced by TSSM $(15,16)$.

\section{Neoseiulus californicus}

Neoseiulus (formerly Amblyseius) californicus McGregor (Acari: Phytoseiidae) is another species of predatory mite that is commercially available as a biological control agent (11). Wild populations of $N$. californicus occur on fruit, vegetable, and ornamental crops throughout the world in temperate and subtropical regions (17). Like P. persimilis, $N$. californicus has a preference for feeding on mites in the 
family Tetranychidae, and it is commonly employed in cultivated crops against TSSM (Figure 4) (11). However, $N$. californicus is highly polyphagous, as compared to the narrow host range of $P$. persimilis. Neoseiulus californicus can subsist on different mite species, small insects, and even pollen in the absence of preferred prey items (18, 19). Whereas $P$. persimilis populations tend to perish when TSSM resources have been exhausted, $N$. californicus can establish permanent populations when it is introduced into new areas. Some of the biological attributes contributing to the success of $N$. californicus in colonizing new areas include its acceptance of a wide range of prey items, generally low food requirements, and low tendency for cannibalism $(11,20,21)$. Neoseiulus californicus has also demonstrated an ability to develop resistant to pesticides, favoring its persistence in cropping systems where pesticides are used selectively and in moderation $(22,23,24)$. Neoseiulus californicus favors warm temperatures, but can withstand a range of $10^{\circ} \mathrm{C}-33^{\circ} \mathrm{C}\left(50^{\circ} \mathrm{F}-91^{\circ} \mathrm{F}\right)$, with a preference for 40\%-80\% relative humidity (25). Neoseiulus californicus lay an average of 2 eggs per day and have an adult lifespan of $\sim 20$ days, with total lifecycle development time ranging from 26-37 days (25).

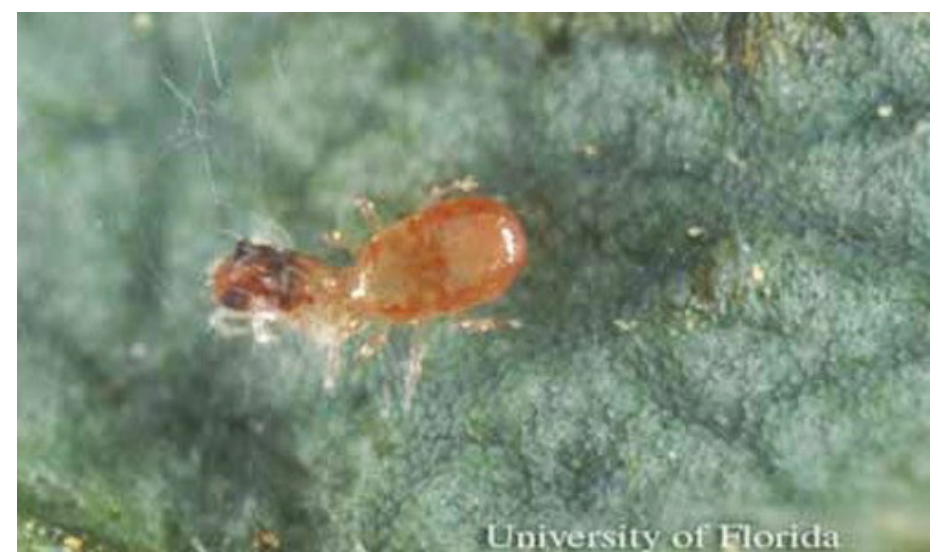

Figure 4. Adult Neoseiulus californicus attacking a twospotted spider mite (Tetranychus urticae).

Credits: Lyle Buss, University of Florida

Adult $P$. persimilis have been shown to consume up to 3 times more TSSM than adult N. californicus (26). The lower rate of TSSM consumption by $N$. californicus causes for a slower reduction in TSSM populations, but suppression of TSSM can be sustained over a longer period than with $P$. persimilis (17). Release rates of $1 \mathrm{~N}$. californicus adult per 10 TSSM have been shown to effectively suppress TSSM. Different application techniques have been examined, with a predator-in-first technique (low release rates prior to TSSM detection) and site-specific releases (targeting specific "hot spot" areas in infested fields), showing good suppression results at lower cost to the grower $(25,27)$.

\section{Chemical Pesticides}

Approximately 15\% of Florida strawberries are produced with the use of predatory mites to control TSSM (1). However, severe TSSM outbreaks and the management of other, less common insect and mite pests regularly require the use of chemical insecticides and miticides (1). Given the importance of the biological control services provided by P. persimilis and N. californicus in this production system, there is a need to understand potential detrimental effects of pesticides on beneficial predators $(28,29)$.

Koppert Biological Systems and Biobest Sustainable Crop Management, distributors of commercial predatory mite formulations, produce side-effect manuals designed to summarize the compatibility of common commercial chemical products with beneficial organisms. These manuals can be of significant value to growers, allowing them to anticipate potentially antagonistic interactions among management efforts while addressing complex pest problems. Understanding the potential for undesirable, non-target effects of chemical sprays gives growers the opportunity to plan pesticide application timing to minimize exposure of predator releases, or to select reduced risk pesticides when beneficial organisms are present in the field.

The side-effect manuals can be found at the following links:

https://www.koppert.com/side-effects/

https://www.biobestgroup.com/en/side-effect-manual

The Vegetable Production Handbook of Florida (2017-2018) lists 63 pesticide products as registered for use against arthropod pests in Florida strawberries, including 42 conventional products and 21 OMRI-listed (Organic Materials Review Institute) organic formulations. Appendices $\mathrm{A}$ and $\mathrm{B}$ has been developed as a tool for growers and extension personnel to cross-reference the effect of each of these products (as well as the most recently registered Nexter WP miticide and Exirel insecticide) on P. persimilis and $N$. californicus.

The toxic effects in the appendix tables are categorized as non-toxic (i.e. causing less than $25 \%$ mortality in $P$. persimilis and/or N. californicus), slightly toxic (25-50\%), moderately toxic (50-75\%), and highly toxic (>75\%). Appendix A summarizes all of the products registered for use in conventional fields, and appendix B summarizes all of the products registered for use in organic fields (OMRIlisted products). Commercial formulations containing a combination of two different active ingredients are 
assigned the rating of the most toxic component. The data summarized from the side-effects manuals is comprised of mortality rates resulting from foliar spray applications on motile (adult and nymph) stages of predatory mites. When the toxic effects reported in the manuals are inconsistent, a range representing values in both manuals is reported.

Among conventional insecticides and miticides (Appendix A), nearly as many products are rated as highly toxic to both predator species (8) as those rated non-toxic (9), with the majority of products (27) falling into an intermediate toxicity range. Florida strawberry producers have some pest management alternatives that offer reduced risks to beneficial predatory mites. Among OMRI-listed organic pesticides (Appendix B), only M-pede (potassium salts of fatty acids) is rated as highly toxic to both predator species, with five formulations of Bacillus thuringiensis rated as non-toxic to both species. While the toxicity ratings of most products are similar for both predator species, $N$. californicus is, generally, less susceptible to insecticides than $P$. persimilis. Nine conventional products are rated as highly toxic to N. californicus, versus 13 for $P$. persimilis, while 11 products rank as non-toxic to both species. Among OMRIlisted products, there are 9 non-toxic products and 1 highly toxic product affecting N. californicus, as compared to 6 non-toxic and 2 highly toxic products affecting $P$. persimilis. These summaries can serve as a useful tool to growers, helping to inform decisions on insecticide and miticide applications in strawberry fields.

\section{Sources}

1. Mossler, M. 2012. Florida Crop/Pest Management Profiles: Strawberry. CIR1239. Gainesville: Institute of Food and Agricultural Sciences. http://edis.ifas.ufl.edu/pi037

2. Marinosci, C., S. Magalhães, E. Macke, M. Navajas, D. Carbonell, C. Devaux, and I. Olivieri. 2015. "Effects of host plant on life-history traits in the polyphagous spider mite Tetranychus urticae." Ecology and Evolution. 5: 3151-3158

\section{Fasulo, T. R. and H. A. Denmark. 2009. Twospotted} spider mite. EENY150. Gainesville: Institute of Food and Agricultural Sciences. http://edis.ifas.ufl.edu/in307

4. Arthropod Pesticide Resistance Database. "Tetranychus urticae." https://www.pesticideresistance.org/display. php? page $=$ species\&arId $=536$.

5. Van Leeuwen, T., J. Vontas, A. Tsagkarakou, W. Dermauw, and L. Tirry. 2010. "Acaricide resistance mechanisms in the two-spotted spider mite Tetranychus urticae and other important Acari: a review." Insect Biochemistry and Molecular Biology. 40(8): 563-572.

6. Ashihara, W., T. Hamamura, and N. Shinkaji. 1978. "Feeding reproduction, and development of Phytoseiulus persimilis Athias-Henriot (Acarina:Phytoseiidae) on various food substances." Bull. Fruit Tree Res. Stn. Ser. E. 2: 91-98.

7. Van den Boom, C. E. M., T. A. Van Beek, and M. Dicke. 2002. "Attraction of Phytoseiulus persimilis (Acari: Phytoseiidae) towards volatiles from various Tetranychus urticae-infested plant species." Bulletin of Entomological Research. 92(6): 539-546.

8. Chant, D. A. 1961. "An experiment in biological control of Tetranychus telarius (L.) (Acarina: Tetranychidae) in a greenhouse using the predacious mite Phytoseiulus persimilis Athias-Henriot (Phytoseiidae)." The Canadian Entomologist. 93(6): 437-443.

9. Laing, J. E. and C. B. Huffaker. 1969. "Comparative studies of predation by Phytoseiulus persimilis AthiasHenriot and Metaseiulus occidentalis (Nesbitt) (Acarina: Phytoseiidae) on populations of Tetranychus urticae koch (Acarina: Tetranychidae)." Researches on Population Ecology. 11(1): 105-126.

10. McMurtry, J. A. 1977. "Some predaceous mites [Phytoseiidae] on citrus in the Mediterranean region." BioControl. 22(1): 19-30.

11. McMurtry, J.A. and A. B. Croft. 1997. "Life-styles of Phytoseiidae mites and their roles in biological control." Annual Review of Entomology. 42: 291-321.

12. Hoffmann, M. P. and A. C. Frodsham. 1993. Natural Enemies of Vegetable Insect Pests. Ithaca: Cornell University Cooperative Extension. 63 pp.

13. Cross, J. V. 1984. "Biological control of two-spotted spider mite (Tetranychus urticae) by Phytoseiulus persimilis on strawberries grown in walk-in plastic tunnels, and a simplified method of spider mite population assessment." Plant Pathology. 33(3): 417-423.

14. Wysoki M. 1985. "Outdoor crops." In: World Crop Pests. Spider Mites. Their Biology, Natural Enemies and Control, Vol. 1B. Edited by W. Helle and M. W. Sabelis. pp. 375-384. Elsevier, Amsterdam. 
15. Sznajder, B., M. W. Sabelis, and M. Egas. 2011. "Innate Responses of the Predatory Mite Phytoseiulus Persimilis to a Herbivore-Induced Plant Volatile." Experimental \& Applied Acarology. 54: 125-138.

16. McMurtry, J. A. 1982. "The use of phytoseiids for biological control: progress and future prospects." In Recent advances in knowledge of the Phytoseiidae. pp. 23-48.

17. Rhodes, E. M. and O. E. Liburd. 2006. "Evaluation of predatory mites and Acramite for control of twospotted spider mites in strawberries in north central Florida." Journal of Economic Entomology. 99(4): 1291-1298.

18. Schausberger, P. and A. Walzer. 2001. "Combined versus single species release of predaceous mites: predatorpredator interactions and pest suppression." Biological Control. 20(3): 269-278

19. Castagnoli, M., M. Liguori, and S. Simoni. 1999. "Effect of two different host plants on biological features of Neoseiulus californicus (McGregor)." International Journal of Acarology. 25(2):145-150.

20. Castagnoli, M. and L. Falchini. 1993. "Suitability of Polyphagotarsonemus latus (Banks) (Acari Tarsonemidae) as prey for Amblyseius californicus (McGregor) (Acari Phytoseiidae)." Redia. 76: 273-279.

21. Croft, B. A., L. N. Monetti, and P. D. Pratt. 1998. "Comparative life histories and predation types: are Neoseiulus californicus and N. fallacies (Acari: Phytoseiidae) similar type II selective predators of spider mites." Environmental Entomology. 27: 531-538.

22. Croft, B. A. 1990. "Developing a philosophy and program of pesticide resistance management." In Pesticide resistance in arthropods. pp. 277-296.

23. Blümel, S. 1999. "Susceptibility of Neoseiulus californicus to pesticides in the laboratory compared to other predatory mites." In October meeting of the IOBC/WPRS WG Pesticides and Beneficial Organisms. 26:30.

24. Castagnoli, M., M. Liguori, S. Simoni, and C. Duso. 2005. "Toxicity of some insecticides to Tetranychus urticae, Neoseiulus californicus and Tydeus californicus." BioControl. 50(4): 611-622.
25. Rhodes, E. M. and O. E. Liburd. 2015. Neoseiulus californicus (McGregor) (Arachnida: Acari: Phytoseiidae). EENY359. Gainesville: Institute of Food and Agricultural Sciences. http://edis.ifas.ufl.edu/in639

26. Gilstrap, F. E. and D. D. Friese. 1985. “The predatory potential of Phytoseiulus persimilis, Amblyseius californicus, and Metaseiulus occidentalis (Acarina: Phytoseiidae)." International Journal of Acarology. 11(3): 163-168.

27. Liu R., T. W. Nyoike, and O. E. Liburd. 2016. "Evaluation of site-specific tactics using bifenazate and Neoseiulus californicus for management of Tetranychus urticae (Acari: Tetranychidae) in strawberries." Experimental and Applied Acarology. 70: 189-204.

28. Fraulo, A.B. and O. E. Liburd. 2007. "Biological control of twospotted spider mite, Tetranychus urticae, with predatory mite, Neoseiulus californicus, in strawberries." Experimental and Applied Acarology. 43(2): 109.

29. Cross, J. V., M. A. Easterbrook, A. M. Crook, D. Crook, J. D. Fitzgerald, P. J. Innocenzi, C. N. Jay, M. G. Solomon. 2001. "Review: Natural enemies and biocontrol of pests of strawberry in northern and central Europe." Biocontrol Science and Technology. 11(2): 165-216. 
Appendix A. Summary of non-target toxicity classifications to Phytoseiulus persimilis and Neoseiulus californicus for selected conventional insecticides and miticides approved for managing arthropod pests of strawberry in Florida as reported in the Side Effects Manuals produced by Koppert Biological Systems and Biobest Sustainable Crop Management.

\begin{tabular}{|c|c|c|c|c|c|c|}
\hline Product & $\begin{array}{l}\text { Toxicity to } P . \\
\text { persimilis }\end{array}$ & $\begin{array}{l}\text { Toxicity to } N . \\
\text { californicus }\end{array}$ & Active ingredient & $\begin{array}{l}\text { Mode of } \\
\text { action }\end{array}$ & Application rate/A & Pests targeted \\
\hline Acramite 50 WS & slightly toxic & non-toxic & bifenazate & $20 \mathrm{D}$ & $0.75-1.0 \mathrm{lb}$ & mites \\
\hline Actara & highly toxic & slightly toxic & thiamethoxam & $4 \mathrm{~A}$ & $1.5-4.0 \mathrm{oz}$ & $\begin{array}{c}\text { aphids, fruit flies } \\
\text { \& spotted wing } \\
\text { drosophila, whiteflies }\end{array}$ \\
\hline Admire Pro & highly toxic & highly toxic & imidacloprid & $4 \mathrm{~A}$ & $\begin{array}{l}\text { soil: } 10.5-14 \text { fl oz } \\
\text { foliar: } 1.3 \text { fl oz }\end{array}$ & $\begin{array}{c}\text { aphids, beetles/weevils, } \\
\text { caterpillars, fruit flies } \\
\text { and spotted wing } \\
\text { drosophila, grubs, } \\
\text { whiteflies }\end{array}$ \\
\hline Agri-Mek 0.15 EC & highly toxic & highly toxic & abamectin & 6 & $16 \mathrm{oz}$ & mites \\
\hline Agri-Mek SC & highly toxic & highly toxic & abamectin & 6 & $3.5 \mathrm{oz}$ & mites \\
\hline Assail 30 SG & $\begin{array}{l}\text { moderately to } \\
\text { highly toxic }\end{array}$ & moderately toxic & acetamiprid & $4 \mathrm{~A}$ & $1.9-6.9 \mathrm{oz}$ & $\begin{array}{l}\text { aphids, armyworms, } \\
\text { beetles/weevils, } \\
\text { caterpillars, fruit } \\
\text { flies \& spotted wing } \\
\text { drosophila, seed bugs, } \\
\text { thrips, whiteflies }\end{array}$ \\
\hline Assail 70 WP & $\begin{array}{l}\text { moderately to } \\
\text { highly toxic }\end{array}$ & moderately toxic & acetamiprid & $4 \mathrm{~A}$ & $0.8-3.0 \mathrm{oz}$ & $\begin{array}{l}\text { aphids, armyworms, } \\
\text { beetles/weevils, } \\
\text { caterpillars, fruit flies } \\
\text { and spotted wing } \\
\text { drosophila, seed bugs, } \\
\text { thrips, whiteflies }\end{array}$ \\
\hline Athena & highly toxic & highly toxic & $\begin{array}{c}\text { bifenthrin \& } \\
\text { avermectin B1 }\end{array}$ & $3 A+6$ & $7.0-17.0$ fl oz & $\begin{array}{c}\text { aphids, armyworms, } \\
\text { beetles/weevils, mites, } \\
\text { seed bugs, whiteflies }\end{array}$ \\
\hline Beleaf 50 SG & non-toxic & non-toxic & flonicamid & 29 & $2.8 \mathrm{oz}$ & aphids, seed bugs \\
\hline Brigade WSB & highly toxic & highly toxic & bifenthrin & $3 A$ & $6.4-32.0 \mathrm{oz}$ & $\begin{array}{c}\text { aphids, armyworms, } \\
\text { beetles/weevils, fruit } \\
\text { flies and spotted wing } \\
\text { drosophila, mites, seed } \\
\text { bugs }\end{array}$ \\
\hline Brigadier & highly toxic & highly toxic & $\begin{array}{l}\text { bifenthrin \& } \\
\text { imidacloprid }\end{array}$ & $3 A+4 A$ & $5.1-6.14 \mathrm{fl} \mathrm{oz}$ & $\begin{array}{l}\text { aphids, armyworms, } \\
\text { beetles/weevils, seed } \\
\text { bugs, whiteflies }\end{array}$ \\
\hline Carbaryl 4 L & $\begin{array}{l}\text { moderately to } \\
\text { highly toxic }\end{array}$ & moderately toxic & carbaryl & $1 \mathrm{~A}$ & $1-2$ quarts & $\begin{array}{l}\text { aphids, caterpillars, } \\
\text { crickets, cockroaches, } \\
\text { seed bugs }\end{array}$ \\
\hline Coragen & non-toxic & non-toxic & chlorantraniliprole & 28 & $3.5-7.5$ fl oz & armyworms \\
\hline Courier SC & non-toxic & non-toxic & buprofezin & 16 & $9.0-13.6 \mathrm{oz}$ & whiteflies \\
\hline Danitol 2.4 EC & highly toxic & moderately toxic & fenpropathrin & $3 \mathrm{~A}$ & $10.67-21.33 \mathrm{fl} \mathrm{oz}$ & $\begin{array}{c}\text { armyworms, beetles/ } \\
\text { weevils, fruit flies } \\
\text { and spotted wing } \\
\text { drosophila, mites, seed } \\
\text { bugs }\end{array}$ \\
\hline Diazinon 50W & slightly toxic & slightly toxic & diazinon & 1B & $1-2 \mathrm{lbs}$ & $\begin{array}{l}\text { aphids, caterpillars, } \\
\text { crickets, cockroaches, } \\
\text { mites }\end{array}$ \\
\hline $\begin{array}{c}\text { Diazinon AG600 } \\
\text { WBC }\end{array}$ & slightly toxic & slightly toxic & diazinon & $1 \mathrm{~B}$ & $12.75-25.5 \mathrm{fl} \mathrm{oz}$ & $\begin{array}{c}\text { aphids, caterpillars, } \\
\text { crickets, cockroaches, } \\
\text { mites }\end{array}$ \\
\hline
\end{tabular}




\begin{tabular}{|c|c|c|c|c|c|c|}
\hline Product & $\begin{array}{l}\text { Toxicity to } P . \\
\text { persimilis }\end{array}$ & $\begin{array}{l}\text { Toxicity to } N . \\
\text { californicus }\end{array}$ & Active ingredient & $\begin{array}{l}\text { Mode of } \\
\text { action }\end{array}$ & Application rate/A & Pests targeted \\
\hline Dibrom 8-E & highly toxic & no information & naled & 1B & 1 pint & $\begin{array}{l}\text { aphids, caterpillars, } \\
\text { mites, thrips }\end{array}$ \\
\hline Esteem 0.86 EC & moderately toxic & moderately toxic & pyriproxyfen & 7D & $10 \mathrm{fl} \mathrm{oz}$ & whiteflies \\
\hline Esteem Ant Bait & moderately toxic & moderately toxic & pyriproxyfen & 7 & $1.5-2.0 \mathrm{lbs}$ & ants \\
\hline Evergreen EC 60-6 & highly toxic & highly toxic & $\begin{array}{c}\text { pyrethrins \& } \\
\text { piperonyl butoxide }\end{array}$ & $3 A$ & $2-16 \mathrm{fl} \mathrm{oz}$ & $\begin{array}{l}\text { aphids, armyworms, } \\
\text { fruit flies and spotted } \\
\text { wing drosophila, seed } \\
\text { bugs, thrips, whiteflies }\end{array}$ \\
\hline Exirel & non-toxic & no information & cyantraniliprole & 28 & 10-20.5 fl oz & $\begin{array}{l}\text { caterpillars, fruit flies } \\
\text { and spotted wing } \\
\text { drosophila, mites }\end{array}$ \\
\hline $\begin{array}{c}\text { Extinguish fire } \\
\text { ant bait }\end{array}$ & non-toxic & no information & S-methoprene & $7 \mathrm{~A}$ & See label & ants \\
\hline Govern 4E & moderately toxic & moderately toxic & chlorpyrifos & $1 \mathrm{~B}$ & See label & beetles/weevils, grubs \\
\hline Intrepid 2F & non-toxic & non-toxic & methoxyfenozide & 18 & $6-12 \mathrm{fl} \mathrm{oz}$ & armyworms \\
\hline Kanemite 15 SC & $\begin{array}{l}\text { non-toxic to } \\
\text { slightly toxic }\end{array}$ & non-toxic & acequinocyl & $20 B$ & $21-31 \mathrm{fl} \mathrm{oz}$ & mites \\
\hline Lorsban 75WG & moderately toxic & moderately toxic & chlorpyrifos & $1 \mathrm{~B}$ & $1.33-2.67 \mathrm{lbs}$ & beetles/weevils, grubs \\
\hline Malathion 5EC & slightly toxic & slightly toxic & malathion & 1B & $1.5-3.2$ pints & $\begin{array}{l}\text { aphids, caterpillars, } \\
\text { crickets, cockroaches, } \\
\text { mites, seed bugs, thrips, } \\
\text { whiteflies }\end{array}$ \\
\hline Malathion $8 \mathrm{~F}$ & slightly toxic & slightly toxic & malathion & $1 \mathrm{~B}$ & $1.5-2.0$ pints & $\begin{array}{l}\text { aphids, caterpillars, } \\
\text { crickets, cockroaches, } \\
\text { mites, seed bugs, thrips, } \\
\text { whiteflies }\end{array}$ \\
\hline Nealta & non-toxic & non-toxic & cyflumetofen & 25 & $13.7 \mathrm{fl} \mathrm{oz}$ & mites \\
\hline Nexter 75 WP & highly toxic & highly toxic & pyridaben & $21 \mathrm{~A}$ & $1.6-3.3 \mathrm{lbs}$ & mites \\
\hline Oberon 2SC & moderately toxic & moderately toxic & spiromesifen & 23 & $12-16$ fl oz & mites, whiteflies \\
\hline Platinum 75 SG & highly toxic & moderately toxic & thiamethoxam & $4 \mathrm{~A}$ & $1.7-4.01 \mathrm{oz}$ & aphids, grubs, whiteflies \\
\hline Portal XLO & $\begin{array}{l}\text { moderately to } \\
\text { highly toxic }\end{array}$ & moderately toxic & fenpyroximate & $21 \mathrm{~A}$ & 2 pints & mites, whiteflies \\
\hline Radiant SC & moderately toxic & highly toxic & spinetoram & 5 & $6-10 \mathrm{fl} \mathrm{oz}$ & $\begin{array}{c}\text { armyworms, caterpillars, } \\
\text { thrips }\end{array}$ \\
\hline Rimon 0.83EC & non-toxic & non-toxic & novaluron & 15 & $9-12 \mathrm{fl} \mathrm{oz}$ & $\begin{array}{c}\text { armyworms, beetles/ } \\
\text { weevils, crickets, } \\
\text { cockroaches, seed bugs }\end{array}$ \\
\hline Savey 50 DF & non-toxic & non-toxic & hexythiazox & $10 \mathrm{~A}$ & $6 \mathrm{oz}$ & mites \\
\hline Sevin 4F & $\begin{array}{l}\text { moderately to } \\
\text { highly toxic }\end{array}$ & moderately toxic & carbaryl & $1 \mathrm{~A}$ & $1-2$ quarts & $\begin{array}{c}\text { armyworms, caterpillars, } \\
\text { seed bugs }\end{array}$ \\
\hline Sevin 80 Solupak & $\begin{array}{l}\text { moderately to } \\
\text { highly toxic }\end{array}$ & moderately toxic & carbaryl & $1 \mathrm{~A}$ & $1.25-2.5 \mathrm{lbs}$ & $\begin{array}{c}\text { armyworms, caterpillars, } \\
\text { seed bugs }\end{array}$ \\
\hline Sivanto Prime & no information & no information & flupyradifurone & 4D & $7-14$ fl oz & aphids, whiteflies \\
\hline Vendex 50 WP & non-toxic & non-toxic & fenbutatin oxide & $12 B$ & $1.5-2.0 \mathrm{lbs}$ & mites \\
\hline Vetica & non-toxic & non-toxic & $\begin{array}{l}\text { buprofezin \& } \\
\text { flubendiamide }\end{array}$ & $16+28$ & $12.0-18.5$ fl oz & whiteflies \\
\hline Voliam Flexi & highly toxic & moderately toxic & $\begin{array}{l}\text { thiamethoxam \& } \\
\text { chlorantraniliprole }\end{array}$ & $4 A+28$ & $2-5 o z$ & $\begin{array}{c}\text { aphids, armyworms, } \\
\text { whiteflies }\end{array}$ \\
\hline Zeal & moderately toxic & moderately toxic & etoxazole & $10 \mathrm{~B}$ & $2-3 o z$ & mites \\
\hline
\end{tabular}


Appendix B. Summary of non-target toxicity classifications to Phytoseiulus persimilis and Neoseiulus californicus for selected OMRI listed insecticides and miticides approved for managing arthropod pests of strawberry in Florida as reported in the Side Effects Manuals produced by Koppert Biological Systems and Biobest Sustainable Crop Management.

\begin{tabular}{|c|c|c|c|c|c|c|}
\hline Product & $\begin{array}{l}\text { Toxicity to } P \text {. } \\
\text { Persimilis }\end{array}$ & $\begin{array}{l}\text { Toxicity to } N . \\
\text { Californicus }\end{array}$ & Active Ingredient & $\begin{array}{l}\text { Mode of } \\
\text { Action }\end{array}$ & $\begin{array}{l}\text { Application } \\
\text { Rate }\end{array}$ & Pests Targeted \\
\hline Agree WG & non-toxic & non-toxic & $\begin{array}{c}\text { Bacillus thuringiensis } \\
\text { subspecies aizawai strain } \\
\text { GC-91 }\end{array}$ & $11 \mathrm{~A}$ & $0.5-2.0 \mathrm{lbs}$ & armyworms \\
\hline Aza-Direct & $\begin{array}{l}\text { slightly to } \\
\text { moderately } \\
\text { toxic }\end{array}$ & non-toxic & azadirachtin & -- & $1-2$ pints & $\begin{array}{l}\text { aphids, armyworms, } \\
\text { crickets, cockroaches, fruit } \\
\text { flies and spotted wing } \\
\text { drosophila, mites, thrips, } \\
\text { whiteflies }\end{array}$ \\
\hline Azera & highly toxic & non-toxic & $\begin{array}{l}\text { azadirachtin \& } \\
\text { pyrethrins }\end{array}$ & $3 \mathrm{~A}$ & See label & $\begin{array}{l}\text { aphids, armyworms, } \\
\text { beetles/weevils, } \\
\text { caterpillars, thrips, } \\
\text { whiteflies }\end{array}$ \\
\hline Biobit HP & non-toxic & non-toxic & $\begin{array}{c}\text { Bacillus thuringiensis } \\
\text { subspecies kurstaki }\end{array}$ & $11 \mathrm{~A}$ & $0.5-2.0 \mathrm{lbs}$ & armyworms, caterpillars \\
\hline Botanigard ES & no information & no information & $\begin{array}{c}\text { Beauvaria bassiana } \\
\text { strain GHA }\end{array}$ & -- & $0.25-1$ quart & $\begin{array}{c}\text { aphids, caterpillars, } \\
\text { crickets, cockroaches, } \\
\text { grubs, seed bugs, thrips, } \\
\text { whiteflies }\end{array}$ \\
\hline Deliver & non-toxic & non-toxic & $\begin{array}{c}\text { Bacillus thuringiensis } \\
\text { subspecies kurstaki }\end{array}$ & $11 \mathrm{~A}$ & $0.25-1.5 \mathrm{lbs}$ & armyworms, caterpillars \\
\hline DiPel DF & non-toxic & non-toxic & $\begin{array}{c}\text { Bacillus thuringiensis } \\
\text { subspecies kurstaki }\end{array}$ & $11 \mathrm{~A}$ & $0.5-2.0 \mathrm{lbs}$ & armyworms, caterpillars \\
\hline Entrust & slightly toxic & moderately toxic & spinosad & 5 & $1.25-1.5 \mathrm{oz}$ & $\begin{array}{l}\text { armyworms, caterpillars, } \\
\text { fruit flies and spotted wing } \\
\text { drosophila, thrips }\end{array}$ \\
\hline Grandevo & no information & no information & $\begin{array}{c}\text { Chromobacterium } \\
\text { subtsugae strain PRAA4- } \\
1\end{array}$ & -- & $1-3 \mathrm{lbs}$ & $\begin{array}{c}\text { aphids, armyworms, } \\
\text { caterpillars, mites, thrips, } \\
\text { whiteflies }\end{array}$ \\
\hline Javelin WG & non-toxic & non-toxic & $\begin{array}{l}\text { Bacillus thuringiensis } \\
\text { subspecies kurstaki }\end{array}$ & $11 \mathrm{~A}$ & $0.25-1.5 \mathrm{lbs}$ & armyworms, caterpillars \\
\hline JMS Stylet Oil & $\begin{array}{l}\text { moderately } \\
\text { toxic }\end{array}$ & moderately toxic & paraffinic (mineral) oil & -- & $\begin{array}{l}3 \text { quarts } / 100 \\
\text { gal water }\end{array}$ & mites, whiteflies \\
\hline MET52 EC & no information & no information & $\begin{array}{l}\text { Metarhizium anisopliae } \\
\text { strain F52 }\end{array}$ & -- & $\begin{array}{l}\text { Drench: } \\
40-80 \text { fl } \\
\text { oz/100 }\end{array}$ & $\begin{array}{l}\text { beetles/weevils, mites, } \\
\text { thrips, whiteflies }\end{array}$ \\
\hline M-Pede & highly toxic & highly toxic & $\begin{array}{l}\text { potassium salts of fatty } \\
\text { acids }\end{array}$ & -- & See label & aphids, mites, whiteflies \\
\hline Mycotrol ESO & no information & no information & $\begin{array}{c}\text { Beauvaria bassiana } \\
\text { strain GHA }\end{array}$ & -- & $0.25-1$ quart & $\begin{array}{l}\text { aphids, beetles/weevils, } \\
\text { caterpillars, crickets, } \\
\text { cockroaches, grubs, seed } \\
\text { bugs, thrips, whiteflies }\end{array}$ \\
\hline Neemix $4.5 \%$ EC & $\begin{array}{l}\text { slightly to } \\
\text { moderately } \\
\text { toxic }\end{array}$ & non-toxic & azadirachtin & -- & $4-16$ fl oz & $\begin{array}{l}\text { aphids, armyworms, } \\
\text { caterpillars, thrips, } \\
\text { whiteflies }\end{array}$ \\
\hline PFR-97 20\%WDG & no information & no information & $\begin{array}{l}\text { Isaria fumosoroseus } \\
\text { Apopka strain } 97\end{array}$ & -- & $1-2 \mathrm{lbs}$ & $\begin{array}{c}\text { aphids, caterpillars, } \\
\text { mites, seed bugs, thrips, } \\
\text { whiteflies }\end{array}$ \\
\hline PyGanic EC 5.0 & no information & no information & pyrethrins & $3 \mathrm{~A}$ & See label & $\begin{array}{l}\text { aphids, armyworms, fruit } \\
\text { flies and spotted wing } \\
\text { drosophila, seed bugs, } \\
\text { thrips, whiteflies }\end{array}$ \\
\hline
\end{tabular}




\begin{tabular}{|c|c|c|c|c|c|c|}
\hline Product & $\begin{array}{l}\text { Toxicity to } P \text {. } \\
\text { Persimilis }\end{array}$ & $\begin{array}{l}\text { Toxicity to } N . \\
\text { Californicus }\end{array}$ & Active Ingredient & $\begin{array}{l}\text { Mode of } \\
\text { Action }\end{array}$ & $\begin{array}{l}\text { Application } \\
\text { Rate }\end{array}$ & Pests Targeted \\
\hline SuffOil-X & no information & no information & $\begin{array}{c}\text { unsulfonated residue of } \\
\text { petroleum oil }\end{array}$ & -- & 1-2 gallons & aphids, mites, whiteflies \\
\hline Trilogy & $\begin{array}{l}\text { moderately } \\
\text { toxic }\end{array}$ & moderately toxic & neem oil & -- & $0.5-2 \%$ & aphids, mites \\
\hline Venerate XC & no information & no information & $\begin{array}{l}\text { Burkholderia spp. Strain } \\
\text { A396 }\end{array}$ & -- & $1-8$ quarts & caterpillars \\
\hline Xentari & non-toxic & non-toxic & $\begin{array}{c}\text { Bacillus thuringiensis } \\
\text { subspecies aizawai }\end{array}$ & $11 \mathrm{~A}$ & $0.5-2.0 \mathrm{lbs}$ & armyworms, caterpillars \\
\hline
\end{tabular}

